\title{
Pathogenic bacteria for human and fish isolated from fish farm in Kastamonu, Turkey
}

\begin{abstract}
The danger of zoonotic diseases is increasing day by day for human. A lot of bacteria lives high concentrate in the water environment. Also the bacterial flora of the aquatic organisms is determined by the environment in which it lives. According to, this the objective of the study was to evaluate, examine, research and monitoring the condition of the pathogenic bacteria for human and fish in the fish farms of Kastamonu, Turkey. Aeromonashydrophila, Lactococcusgarviae, Vibrio anguillarum and were isolated from fish samples, also Burkholderiacepacia, Pseudomonas aeruginosa and Pseudomonas fluorescens were isolated from water samples. Aeromonashydrophila, Burkholderiacepacia, Pseudomonas aeruginosa and Vibrio fluvialis are zoonotic bacteria, and Lactococcusgarviae is a circuitously dangerous for human health.According to this study results, fish producers must pay attention to hygiene rules and monitoring the aquaculture environment.
\end{abstract}

Keywords: Zoonotic bacteria, Fish pathogens, Water microbiology
Volume 6 Issue 3 - 2017

\author{
Nejdet G Itepe,2 Saleh BA Alkhunni,' Mousa \\ SM Gaballah ${ }^{2,3}$ \\ 'Biotechnology Research Center, Authority of Science Research \\ Technology, Libya \\ ${ }^{2}$ Genetics and Bioengineering Department, Kastamonu \\ University, Turkey \\ ${ }^{3}$ Veterinary Medicine Faculty, Omar Al-Mukhtar University, Libya
}

Correspondence: Nejdet Gültepe, Kastamonu

University, Engineering and Architecture Faculty, Genetics

and Bioengineering Department, Kastamonu,Turkey, Tel:

+905326334769; Email nejgultepe@yhoo.com

Received: September II, 2017 | Published: September 20, 2017

\section{Introduction}

Aquaculture production has showed a rapid growth in the last years. To provide increasing amounts of aquaculture for the world's growing population, many major fish farms are already at maximum capacity; fish are often cultured in limited spaces such as ponds and net cages under high densities, under parameters that depend on the species stocked and prevailing environmental conditions. However, these overcrowding trends adversely affect the health of cultured fish by making them susceptible to infectious diseases. ${ }^{1}$

As in every living organism, human beings are producing a number of waste products while continuing their life, and diseases such as fish and aquatic products are emerging due to the pollution caused by these products, and some of these diseases may show zoonotic characteristics. ${ }^{2}$ Zoonotic diseases can be transmitted to humans through drinking water and, consumption of raw and undercooked fish or similar aquatic products. For these reasons zoonotic organisms are an important for human health.

Enterobacteriaceae spp. can be transmitted to human by consumption of the aquatic organisms and contaminated water. Also Bacillaceae spp. are widely found in fish. ${ }^{3,4}$ Vibrionaceae spp. lives extensively in almost every water source, especially in salty and brackish water. Besides these bacteria are frequently isolated from fish, other aquatic products, and shellfish., ${ }^{2,5}$ Many bacteria of Vibrionaceae, especially non-epidemic isolates of Vibrio vulnificus, Vibrio parahaemolyticus and Vibrio cholera cause the infections for human due to consumption of raw and/or undercooked aquatic products. In contrast, the epidemic Vibrio cholerae isolates are transmitted from environments to water and human. ${ }^{6}$ The most common species of the Vibrionaceae is the Vibrio parahaemolyticus strains. ${ }^{7}$ Aeromonadaceae spp. are more often contaminated to human by water and food. ${ }^{8,9}$ Aeromonadaceae spp. were isolated in $11.1 \%$ of the samples taken from diarrhea patients in Japan between 1985-1987. It has been found that younger human who eat fish products infected with Aeromonadaceae spp. may develop diarrhea and, chronic enterocolitis performs in elderly people, as well as inflammation and vomiting in people contaminating with these bacteria. ${ }^{10,11}$ Salmonella spp. are isolated from fish and other aquatic organisms. Infections of Salmonella spp. are mostly transmitted to human by contaminated water and food. It has been reported that $7 \%$ of Salmonella spp. infections in the United States are related to seafood. ${ }^{12,13}$

Importance of zoonotic diseases are day by day increasing owing to its risks and effects. For this reason, careful evaluation, examination and monitoring of foodstuffs in terms of human health is important. The microbial flora of processed and fresh aquatic organisms should be carefully examined in the evaluating stage. Also the bacterial flora of the aquatic organisms is determined by the environment in which it lives. According to, this the objective of the study was to evaluate, examine, research and monitoring the condition of the pathogenic bacteria for human and fish in the fish farms of Kastamonu, Turkey.

\section{Materials and methods}

There are 11 fish farm in Kastamonu, which are total production capacities 419, $50 \mathrm{t}$ per year, but 5 of them made fish production at all seasons. For this, sample collected from 5 fish farms for the bacteriological analyses at 2015 and 2016. Farm I, II and II based in different streams, Farm IV and V established in a dam lake. Dissolved oxygen, $\mathrm{pH}$, salinity, temperature, conductivity and resistivity are measured in these farm with Hach Lange HQ 40 D multimeter and were given Table 1. Ten fish and water samples were taken in duplicate from each fish farm for the bacteriological investigations. Bacteria were isolated from samples with dilution-plate methods. ${ }^{14} \mathrm{All}$ of the bacteriological media used in this research was from Merck (Merck, Germany). Individual colonies were then identified. ${ }^{15,16} \mathrm{Gram}$ staining, catalase, oxidase and motility were using for presumptive identification of the bacterial strains. Biochemical characteristics of totally 21 bacteria were determined with API 20 E, API 20 STREP and API $50 \mathrm{CH}$ tests (BioMerieux S.S., France) at $25 \pm 0.5^{\circ} \mathrm{C}$ for 48 h. ${ }^{17,18}$

\section{Results and discussion}

There are no find any parasitic infestation in fish farms. Aeromonashydrophila, Lactococcusgarviae, Vibrio 
$\begin{array}{llll}\text { anguillarum and } & \text { Vibrio } & \text { fluvialis } & \text { were } \\ \text { isolated from fish } & \text { samples, also Burkholderi }\end{array}$ acepacia, Pseudomonas aeruginosa and Pseudomonas fluorescens were isolated from water samples. Distribution of the bacteria were given Table 2 in the fish farms. API 20 E, API 20 STREP and API $50 \mathrm{CH}$ tests results were given Table 3-5 respectively.
Aeromonas hydrophila can be find in fresh water, aquatic plants, fish and fish eggs, which is a pathogenic bacterium for both human and fish. It causes high mortality and heavy economically losses in fish farms and also gastroenteritis, vomiting, fever, epigastric pain, septicemia, arthritis, meningitis and peritonitis in humans. ${ }^{16,19}$

Table I Water parameters in the fish farms

\begin{tabular}{llllll}
\hline Parameters & Farm I & Farm II & Farm III & Farm IV & Farm V \\
\hline Dissolved $\mathrm{O}_{2}\left(\mathrm{mg} \mathrm{L}^{-1}\right)$ & 8.60 & 8.56 & 8.62 & 9.58 & 9.50 \\
$\mathrm{pH}$ & 8.96 & 8.78 & 8.82 & 8.68 & 8.65 \\
Temperature $\left({ }^{\circ} \mathrm{C}\right)$ & 10.70 & 10.40 & 10.50 & 17.50 & 17.30 \\
Salinity $\left(\mathrm{mg} \mathrm{L}^{-1}\right)$ & 0.22 & 0.22 & 0.22 & 0.21 & 0.21 \\
Conductivity $\left(\mathrm{ms} \mathrm{cm}^{-1}\right)$ & 462 & 465 & 453 & 434 & 430 \\
Resistivity $(\Omega)$ & 2165 & 2154 & 2161 & 2054 & 2050 \\
\hline
\end{tabular}

Table 2 Isolated bacteria species in the fish farms

\begin{tabular}{llllll}
\hline Parameters & Farm I & Farm II & Farm III & Farm IV & Farm V \\
\hline Aeromonas hydrophila & + & & + & & \\
Burkholderia cepacia & & & & & + \\
Lactococcus garvieae & & & & + & + \\
$\begin{array}{l}\text { Pseudomonas aeruginosa } \\
\text { Pseudomonas fluorescens }\end{array}$ & + & + & & + & + \\
$\begin{array}{l}\text { Vibrio anguillarum } \\
\text { Vibrio fluvialis }\end{array}$ & & & & \\
\hline
\end{tabular}

+ : positive (isolated)

Table 3 Isolated bacteria from fish farms according to API 20 E tests results

\begin{tabular}{|c|c|c|c|c|c|c|c|c|c|}
\hline \multirow{2}{*}{ Properties } & \multicolumn{2}{|l|}{ Farm I } & \multirow{2}{*}{$\begin{array}{l}\text { Farm II } \\
\text { P.aeruginosa }\end{array}$} & \multicolumn{2}{|l|}{ Farm III } & \multicolumn{2}{|l|}{ Farm IV } & \multicolumn{2}{|l|}{ Farm V } \\
\hline & A.hydrophila & P.aeruginosa & & A.hydrophila & V.fluvialis & P.fluorescens & P.aeruginosa & V.anguillarum & B.cepacia \\
\hline Gram stain & - & - & - & - & - & - & - & - & - \\
\hline Motility & + & + & + & + & + & + & + & + & + \\
\hline Oxidase & + & + & + & + & - & + & + & + & + \\
\hline Catalase & + & + & + & + & + & + & + & + & + \\
\hline ONPG & + & - & - & + & + & - & - & + & - \\
\hline $\mathrm{ADH}$ & + & + & + & + & + & - & + & + & + \\
\hline LDC & + & - & - & + & + & - & - & - & + \\
\hline ODC & - & - & - & - & - & - & - & - & + \\
\hline CIT & + & + & + & + & + & + & + & + & + \\
\hline $\mathrm{H}_{2} \mathrm{~S}$ & - & - & - & - & + & - & - & - & - \\
\hline URE & - & + & + & - & - & - & + & - & - \\
\hline TDA & - & - & - & - & - & - & - & - & - \\
\hline IND & + & - & - & + & - & - & - & - & - \\
\hline GEL & + & + & + & + & + & - & + & + & - \\
\hline GLU & + & - & - & + & + & - & - & + & - \\
\hline MAN & + & - & - & + & + & - & - & + & - \\
\hline INO & - & - & - & - & - & - & - & + & - \\
\hline SOR & + & - & - & + & + & - & - & + & - \\
\hline RHA & - & - & - & - & - & - & - & - & - \\
\hline SAC & + & - & - & + & + & - & - & + & - \\
\hline MEL & - & - & - & - & - & - & - & - & - \\
\hline AMY & + & - & - & + & + & - & - & - & - \\
\hline ARA & + & - & - & + & + & - & - & + & - \\
\hline OX & + & + & + & + & - & + & + & + & + \\
\hline
\end{tabular}

ONPG, B-galactosidase;ADH,Arginine DiHydrolase; LDC, Lysine DeCarboxylase; ODC, Ornithine DeCarboxylase; CIT, CITrate utilization; $\mathrm{H} 2 \mathrm{~S}$, $\mathrm{H} 2 \mathrm{~S}$ production; URE, UREase; TDA, Tryptophane De Aminase; IND, INDole Production;VP,VogesProskauer; GEL, GELatinase; GLU, GLUcose Fermentation / oxidation; MAN, MANnitol Fermentation / Oxidation; INO, INOsitol Fermentation / Oxidation; SOR, SORbitol Fermentation / Oxidation; RHA, RHAmnose Fermentation / Oxidation; SAC, SACcharose Fermentation / Oxidation; MEL, MELibiose Fermentation / Oxidation,AMY,AMYgdalin Fermentation / Oxidation;ARA, ARAbinose Fermentation / Oxidation; OX, cytochrome-Oxidase 
Table 4 Isolated bacteria from two farms according to API 20 STREP tests results

\begin{tabular}{|c|c|c|}
\hline Properties & $\begin{array}{l}\text { Farm IV } \\
\text { Lactococcusgarvieae }\end{array}$ & $\begin{array}{l}\text { Farm V } \\
\text { Lactococcusgarvieae }\end{array}$ \\
\hline Gram stain & + & + \\
\hline Motility & - & - \\
\hline Oxidase & - & - \\
\hline Catalase & - & - \\
\hline VP & + & + \\
\hline HIP & - & - \\
\hline ESC & + & + \\
\hline PYRA & + & + \\
\hline$\alpha-G A L$ & - & - \\
\hline$\beta$-GUR & - & - \\
\hline$\beta-G A L$ & - & - \\
\hline PAL & - & - \\
\hline LAP & + & + \\
\hline $\mathrm{ADH}$ & + & + \\
\hline RIB & + & + \\
\hline ARA & + & + \\
\hline MAN & + & + \\
\hline SOR & - & - \\
\hline LAC & - & - \\
\hline TRE & + & + \\
\hline INU & - & - \\
\hline RAF & - & - \\
\hline AMD & - & - \\
\hline GLYG & - & - \\
\hline$\beta$-Hemolysis & - & - \\
\hline
\end{tabular}

Abbreviations:VP,Voges Proskauer; HIP, acideHIPpurique; ESC, ESCuline; PYRA, PYRrolidonyl Arylamidase; $\alpha$-GAL, $\alpha$-GALactosidase; $\beta$-GUR, $\beta$-GIUcuRonidase; PAL, Phosphatase ALcaline; LAP, Leucine AminoPeptidase;ADH,Arginine DiHydrolase; RIB, RIBose Acidification;ARA, ARAbinose Acidification; MAN, MANnitol Acidification; SOR, SORbitol Acidification; LAC, LACtose Acidification; TRE, TREhalose Acidification; INU, INUline Acidification; RAF, RAFfinose Acidification; AMD, AMiDon Acidification; GLYG, GLYcoGene Acidification

Table 5 Isolated bacteria from two farms according to API $50 \mathrm{CH}$ tests results

\begin{tabular}{|c|c|c|c|c|c|}
\hline Properties & $\begin{array}{l}\text { Farm IV } \\
\text { L.garvieae }\end{array}$ & $\begin{array}{l}\text { Farm V } \\
\text { L.garvieae }\end{array}$ & Properties & $\begin{array}{l}\text { Farm IV } \\
\text { L.garvieae }\end{array}$ & $\begin{array}{l}\text { Farm V } \\
\text { L. garvieae }\end{array}$ \\
\hline$\overline{\text { GLY }}$ & - & - & SAL & + & + \\
\hline ERY & - & - & CEL & + & + \\
\hline DARA & - & - & MAL & + & + \\
\hline LARA & - & - & LAC & + & + \\
\hline RIB & + & + & MEL & - & - \\
\hline DXYL & - & - & SAC & - & - \\
\hline LXYL & - & - & TRE & + & + \\
\hline ADO & - & - & INU & - & - \\
\hline MDX & - & - & MLZ & - & - \\
\hline GAL & + & + & RAF & - & - \\
\hline GLU & + & + & AMD & - & - \\
\hline FRU & + & + & GLYG & - & - \\
\hline MNE & - & - & XLT & + & + \\
\hline SBE & - & - & GEN & - & - \\
\hline RHA & - & - & TUR & - & - \\
\hline DUL & - & - & LYX & + & + \\
\hline INO & + & + & TAG & - & - \\
\hline MAN & - & - & DFUC & - & - \\
\hline SOR & - & - & LFUC & - & - \\
\hline MDM & - & - & DARL & - & - \\
\hline MDG & + & + & LARL & - & - \\
\hline NAG & + & + & GNT & - & - \\
\hline AMY & + & + & $2 \mathrm{KG}$ & - & - \\
\hline ARB & + & + & $4 K G$ & & \\
\hline ESC & & & & & \\
\hline
\end{tabular}

Abbreviations: GLY, GLYcerol, ERY, ERYthritol, DARA, D-ARAbinose, LARA, L-ARAbinose, RIB, D-RIBose, DXYL, D-XYLose, LXYL, L-XYLose, ADO, D-ADOnitol, MDX, Methyl- $\beta D$-Xylopyranoside, GAL, D-GALactose, GLU, D-GLUcose, FRU, D-FRUctose, MNE, D-MaNnosE, SBE, L-SorBosE, RHA, L-RHAmnose, DUL, DULcitol, INO, INOsitol, MAN, D-Mannitol, SOR, D-SORbitol, MDM, Methyl- $\alpha$ D-Mannopyranoside, MDG, Methyl- $\alpha$ D-Glucopyranoside, NAG, N-AcetyIGlucosamine, AMY, AMYgdaline, ARB, ARButine, ESC, ESCuline, SAL, SALicine, CEL, D-CELlobiose, MAL, D-MALtose, MEL, D-MELibiose, SAC, D-SACcharose, TRE, D-TREhalose, INU, INUline, MLZ, D-MeLeZitose, RAF, D-RAFfinose, AMD, AMiDon, GLYG, GLYcoGene, XLT, XyLiTol, GEN, GENtiobiose, TUR, D-TURanose, LYX, D-LYXose,TAG, D-TAGatose, DFUC, D-FUCose, LFUC, L-FUCose, DARL, D-ARabitoL, LARL, L-ARabitoL, GNT, potassium GlucoNaTe, 2KG, potassium 2-CetoGluconate, 5KG, potassium 5-CetoGluconate. 
Pseudomonas aeruginosa were isolated from Farm I, II and IV. This pathogen causes various lesions and fever in the body for human and fish. ${ }^{16,20}$ Vibrio fluvialis, a zoonotic pathogen that can cause zoonotic infections, is a type of bacterium that is found intensely in a normal environment. It may be dangerous for human health with produces toxins. It is known that this bacterium, which causes gastroenteritis, diarrhea, lesions and bacteremia in humans, causes diseases in shellfish and their eaters. There are contamination and disease risks with consumption of raw and/or undercooked aquatic products. ${ }^{6,21-23}$ V. fluvialis was isolated from Farm III.

Pseudomonas fluorescens bacteria isolated from the production water in Farm IV is among the bacterium commonly found in the waters. It is known to be pathogenic in many species of fish, especially in carp. ${ }^{16,24}$

Lactococcus garvieae isolated from Farm IV and V is known to be a species of pathogenic bacterium that causes heavy economically losses in various fish species all over the world..$^{16}$ It is also an important species in terms of threatening human health. Bacterium was first time isolated from a bovine mastitis case in England. ${ }^{25,26}$ Vibrio anguillarum isolated from fish in Farm V is a pathogenic bacterium causing vibrios is infection in many fish species and high rate of losses in aquaculture. This bacterium, which can be found especially in salty and brackish waters, is causing an outbreak infection in fish farms. . $^{16,18,27}$

Burkholderi acepacia was isolated from water in the Farm V. This bacteria, which is pathogenic for human, can be found in the water and sediment, also cause cystic fibrosis in human. ${ }^{28} \operatorname{Diler}^{29}$ reported that Gram positive coccus, Coryneform and Gram negative bacteria were isolated from rainbow trout microflora.

Similarly, Achromobacter spp., Acinetobacter spp., Aeromonas spp., Bacillus spp., Brevundimonas spp., Comamonas spp., Enterobacter spp., Flavobacterium spp., Hafnia spp., Klebsiella spp., Kluvyera spp., Micrococcus spp., Moraxella spp., Oligella spp., Pantoea spp., Pseudomonas spp., Proteus spp., Rahnella spp. Salmonella spp., Shigella spp., Sphingomonas spp., Staphylococcus spp., Stenotrophomonas spp., Streptococcus spp., Vibrio spp. and Yersinia spp. were isolated from fish farm in Turkey. ${ }^{17,27,30-33}$ The results of these study have a similarity with this research finding.

\section{Conclusion}

Unsurprisingly, Aeromonas hydrophila, Lactococcus garviae, Vibrio anguillarum, Vibrio fluvialis, Burkholderia cepacia, Pseudomonas aeruginosa and Pseudomonas fluorescens were isolated from these farms on account of its natural living environments. It is thought that, this condition is caused by the microbial flora of these water and also this results supported that the production water of the fish is directly related to the bacterial flora of fish. Some of them these bacteria can be cause zoonotic infection for human. For this reason, fish producers must pay attention to hygiene rules and monitoring the aquaculture environment.

\section{Acknowledgements}

This study partially supported that Kastamonu University Scientific Research Projects Coordination Department, which number is KÜBAP-01/2014-02.

\section{Conflicts of Interest}

The authors declare no conflict of interest.

\section{References}

1. Jones D Composition and properties of the family Enterobacteriaceae. Journal of Applied Bacteriology . 1988;65:1s-19s.

2. Bilgehan $\mathrm{H}$ KlinikMikrobiyoloji Özel Bakteriyolojive Bakteri Enfeksiyonlari. Barıș Yayınları, Fakülteler Kitabevi, Bornova- İzmir, Turkey, pp. 1990186.

3. Goepfert JM Bacillus cereus. Compendium of Methods for the Microbiological Examination of Food; Speck ML (Eds.), American Pub. Health Ass. USA, pp. 1976;417-423.

4. Kahla-nakbi AB, Chaieb K, Besbes A, et al. Virulence and enterobacterial repetitive intergenic consensus PCR of Vibrio alginolyticus strains isolated from Tunisian cultured gilthead sea bream and sea bass outbreaks. Veterinary Microbiology. 117(2-4):321-327.

5. Morris JRJG. Cholera and other types of vibriosis: A story of human pandemics and oysters of half shell. Clin Infect Dis. 2003;37(2):272280

6. Feldhusen F. The role of seafood bacterial food-borne diseases Microbes Infect. 20002(13):1651-1660.

7. Cipriano RC, Bullock GL, Pyle SW. Aeromonashydrophila and motile aeromonad septicemias of fish. U.S. Fish and Wildlife Service pp. $1984 ; 2006 ; 1-26$.

8. Cipriano RC, Ford LA, Starliper CE, et al. Control of external Aeromonassalmonicida: Topical disinfection of salmonids with Chloramine-T. Journal of Aquatic Animal Health. 1996;8(1):52-57.

9. Hanninen ML, DivanenP, Koski VH Aeromonas species in fish, fish eggs, shrimp and fresh water. Int J Food Microbiol. 1997;34(1):17-26.

10. Butt AA, Alridge KE, Sanders CV Infections related to the ingestion of seafood Part I: viral and bacterial infections. Lancet Infect Dis. 2004;4(4):201-212.

11. Bean NH, Goulding JS, Daniels MT, Angulo FJ Surveillance of foodborne disease outbreaks-United States, 1988-1992. J Food Protection. 1997;60:1266-1286.

12. Wilson IG, Moore JE Presence of Salmonella spp. and Campylobacter spp. in shellfish. Epidemiol Infect. 1996;116(2):147-153.

13. Gültepe N, Aydın S Pseudomonas elongata infection in scattered mirror carp (Cyprinuscarpio): bacteriology, gross pathology and treatment. Journal of Animal and Veterinary Advances. 2009;8(5):835-838.

14. Plumb JA, Bowser PR Microbial fish disease laboratory manual. Alabama Agricultural Experiment Station, Alabama University, Brown Printing Company, Montgomery, Alabama, USA pp. 1983;92.

15. Austin B, Austin DA Bacterial Fish Pathogens: Disease of Farmed and Wild Fish. Springer, Praxis Publishing, pp. 1999;457.

16. Gültepe N, Tanrikul TT Treatment methods of Flavobacterium psychrophilum: Cause of Rainbow Trout Fry Syndrome (RFTS) and Bacterial Cold-Water Disease (BCWD) in Turkey. Journal of Fisheries International. 2006;1(2-4):102-105.

17. Tanrikul TT, Gültepe N Mix infection in rainbow trout (Oncorhynchus mykissWalbaum): Lactococcus garvieae and Vibrio anguillarum $\mathrm{O} 1$. Journal of Animal and Veterinary Advances. 2011;10(8):1019-1023.

18. İşleyici Ö, Sancak YC Health risks originated from motile Aaeromonads in foods. YYU Veterinary Faculty Journal. 2009;20(2):69-74.

19. Onuk EE, Durmaz Y, ÇiftçiA, et al. Pathogenic bacteria and resistance genes profiles isolated from different fish species. Atatürk University Journal of Veterinary Sciences. 2015;10(3):156-164.

20. Chakraborty S, Nair GB, Shinoda S. Pathogenic vibrios in the nature aquatic environment. Reviews on Environmental Health. 1997;12(2):6380 . 
21. Tsai YH, Hsu RWW, Huang KC, et al. Systemic Vibrio infection presenting as necrotising fasciitis and sepsis. A series of thirteen cases. $\mathrm{J}$ Bone Joint Surg 86-A. 2004;(11):2497-2502.

22. Igbinosa EO, Okoh AI. Vibrio fluvialis: An unusual enteric pathogen of increasing public health concern. Int J Environ Res Public Health. 2010;7(10):3628-3643.

23. Akayli T, Ürkü Ç, Çanak Ö. Antimicrobial susceptibilities of gramnegative bacteria isolated from cultured rainbow trout (Oncorhynchus mykiss, Walbaum 1792). Research Journal of Biological Sciences. 2013;6(2):17-22.

24. Vela AI, Vazquez J, Gibello A, et al. Phenotypic and genetic characterization of Lactococcus garvieae isolated in Spain from Lactococcos is outbreaks and comparison with isolates of other countries and sources. Journal of Clinical Microbiology. 2000;38(10):3791-3795.

25. Collins MD, Farrow FAE, Phillips BA, et al. Streptococcus garvieae sp. nov. and Streptococcus plantarum sp. nov. J Gen Microbiol. 1984;129(11):3427-3431.

26. Tanrikul T. Vibriosis as an epizootik disease of rainbow trout (Onchorynchus mykiss) in Turkey. Pakistan Journal of Biological Sciences. 2007;10(10):1733-1737.
27. Chaparro C, Maurer J, Gutierrez C, et al. Infection with Burkholderia cepacia in Cystic Fibrosis. Am J Respi Criti Care Med. 2001;163(1):4348.

28. Diler Ö, Altun S, Çalikuşu F, et al. A study on qualitative and quantitative bacterial flora of the rainbow trout (Oncorhynchus mykiss) living in different fish farms. Turkish Journal of Veterinary \& Animal Sciences. 200;24:251-259.

29. Sarieyyüpoğlu M. An investigation of aerobic microbial flora of stomach and intestinal flora in rainbow trout. Doğa Bilim Dergisi. 1984;8(3):281-287.

30. Kiliç A, Şeker E, Özcan M, et al. Bacterial flora of rainbow trout (Oncorhynchus mykiss) in farms in Elazig Region. Science and Engineering Journal of Firat University. 2007;19(2):129-132.

31. KorunJ, ToprakHB. The effect of $\mathrm{NaCl}$ on their antibiotic susceptibility motile Aeromonas strains isolated from the intestine of rainbow trout (Oncorhynchus mykiss). Journal of the Faculty of Veterinary Medicine, Kafkas University. 2010;16(2):193-198.

32. Özer S, DemirelM, Us M, YildirimS. Microbial flora of rainbow trout (Oncorhynchus mykiss, Walbaum) hatcheries in Çağlarca, province Mersin-Turkey. Journal of Fisheries Sciences. 2008;2(3):261-271. 